\title{
Effect of co-infection with parasites on severity of COVID-19
}

Teklay Gebrecherkos ${ }^{1}$, Zekarias Gessesse ${ }^{1}$, Yazezew Kebede ${ }^{1}$, Atsbeha Gebreegzabher ${ }^{2}$, Geremew Tasew ${ }^{2}$, Mahmud Abdulkader ${ }^{1}$, Hiluf Ebuy ${ }^{1}$, Abraham Desta ${ }^{3}$, Atakilti Hailu ${ }^{3}$, Vanessa Harris ${ }^{4,5}$, Tobias Rinke de Wit ${ }^{5,6^{*}}$, Dawit Wolday ${ }^{*}$

*Contributed equally \& corresponding authors

${ }^{1}$ Mekelle University College of Health Sciences, Mekelle, Ethiopia

${ }^{2}$ Ethiopian Public Health institute, Addis Ababa, Ethiopia

${ }^{3}$ Tigray Health Research Institute, Mekelle, Ethiopia

${ }^{4}$ Department of Medical Microbiology and Experimental Parasitology, Academic Medical Center, University of Amsterdam, Amsterdam, The Netherlands

${ }^{5}$ Amsterdam Institute of Global Health and Development, Department of Global Health, Amsterdam University, Amsterdam, The Netherlands

6Joep-Lange Institute, Amsterdam, The Netherlands

Correspondence: dawwol@gmail.com; t.rinkedewit@pharmaccess.org

\section{Summary}

Background: Severe acute respiratory syndrome coronavirus 2 (SARS-CoV-2) infection results in a spectrum of clinical presentations. The effect of co-infection with parasites on the clinical features of COVID-19 is unknown.

Methods: We prospectively enrolled consecutive COVID-19 patients and screened them for intestinal parasitic infections. Patients were followed during hospitalization for clinical outcomes. Patients with parasitic co-infection were compared to those without parasitic co-infection. The primary outcome was the proportion of COVID-19 patients who developed severe disease. Factors associated with the development of severe disease were determined by logistic regression.

Results: A total of 515 patients with PCR-confirmed SARS-CoV-2 infection were screened for intestinal parasites, of whom 267 (51.8\%) were co-infected with one or more parasites. Parasitic co-infection correlated inversely with COVID-19 severity. Severe COVID-19 was significantly higher in patients without parasites [47/248 (19.0\%, Cl:14.52-24.35)] than in those with parasites [21/267 (7.9\%, Cl: 5.17-11.79)]; $p<0.0001$. There was a significantly higher proportion of patients who developed severe COVID-19 in the non-protozoa group [56/369 (15.2\%, Cl: 11.85-19.23)] as 
medRxiv preprint doi: https://doi.org/10.1101/2021.02.02.21250995; this version posted February 3, 2021. The copyright holder for this preprint (which was not certified by peer review) is the author/funder, who has granted medRxiv a license to display the preprint in perpetuity.

All rights reserved. No reuse allowed without permission.

compared to the protozoa group [12/146 (8.2\%, Cl: 4.70-14.00)]; $\mathrm{p}=0.036$. Significant higher proportion of the patients presented at baseline with severe COVID-19 in the helminth negative group [57/341 (16.7\%, Cl: $13.10-21.08)]$ than in the group with pre-existing helminth infection [11/174 (6.3\%, Cl: $3.51-11.11)] ; p=0.001$. In addition, after adjustment for age and presence of comorbidities, COVID-19 patients with any parasite co-infection [aOR 0.41 (95\% Cl: $0.22-0.77)$; $\mathrm{p}=0.006$ ], or with protozoa co-infection [aOR $0.45(95 \% \mathrm{Cl}: 0.21-0.98) ; \mathrm{p}=0.044$ ] as well as those with helminth co-infection [aOR 0.37 (95\% Cl: 0.17-0.80); $\mathrm{p}=0.011$ ] had lower probability of developing severe COVID-19 compared with those without parasite, protozoa or helminth coinfection.

Conclusion: Our results suggest that co-infection with parasitic co-infection appears to be associated with reduced COVID-19 severity. The results suggest that parasite-driven immunomodulatory responses may mute hyperinflammation associated with severe COVID-19.

Key words: COVID-19, helminth, parasite, protozoa, SARS-CoV-2, severe disease

\section{Introduction}

Infection with severe acute respiratory syndrome coronavirus 2 (SARS-CoV-2) results in a spectrum of clinical presentations. Whereas most people with COVID-19 develop only asymptomatic or mild illness, at-risk patients can develop severe disease requiring hospitalization and respiratory [1-3]. In severe cases, COVID-19 can be complicated by the acute respiratory distress syndrome (ARDS), sepsis and septic shock, multi-organ failure, including acute kidney injury and cardiac injury [2-4]. Older age and underlying comorbidities due to non-communicable diseases (NCDs) such as hypertension, cardiovascular diseases and diabetes, have been reported as risk factors for disease severity and death [4-8].

Underlying conditions in the setting of low and medium-income countries (LMICs) are different from those in high-income countries (HICs). In LMICs, infectious diseases are highly prevalent than NCDs. One such infectious diseases are neglected infectious disease (NIDs). Most notably, parasitic infections affect more than 2 billion people throughout the world, with disproportionately high prevalence rates in resource-poor settings [9, 10]. Multicellular and highly complex parasites such as Ascaris, hook worm, Trichuris, Enterobius and Schistosoma, as well as unicellular organisms including Entamoeba, Giardia, Toxoplasma, Cyclospora and Cryptosporidia are among the major organisms that contribute to the global intestinal parasitic disease burden $[9,10]$. The distribution of parasitic infections varies widely in the different parts of the world.

Chronic and persistent parasitic infection is common in LIMCs, and chronic parasitic infections, possibly in part through direct modulation of the host's immune responses, have been shown to alter clinical outcomes to other infections $[11,12]$. Pre-existing parasitic infections may also modify the host's immune response to infection with SARS-CoV-2 with possible beneficial or 
medRxiv preprint doi: https://doi.org/10.1101/2021.02.02.21250995; this version posted February 3, 2021. The copyright holder for this preprint (which was not certified by peer review) is the author/funder, who has granted medRxiv a license to display the preprint in perpetuity.

All rights reserved. No reuse allowed without permission.

detrimental effects [13-19]. Recent reports demonstrated an inverse correlation between the incidence of COVID-19 and with soil-transmitted helminths, schistosomiasis or malaria [20]. To the best of our knowledge, however, there have been no studies to date that have assessed the effect of co-infection with parasites on the severity of COVID-19. In this study, therefore, we compared the clinical outcomes of COVID-19 patients with or without parasitic co-infection.

\section{Methods}

\section{Study design and participants}

We identified individuals recruited to the Profile-CoV study who had been screened for parasitic infections. Profile-CoV project (Clinicaltrials.gov: NCT04473365) is a prospective observational cohort study being undertaken in two sites in Ethiopia, with the aim of profiling of immunological response to SARS-CoV-2 in the context of persistent immune activation in Sub-Saharan Africa.

All patients suspected of having SARS-CoV-2 infection were screened for SARS-CoV-2 infection with a nasopharyngeal real-time polymerase chain reaction (RT-PCR). All patients with confirmed SARS-CoV-2 infection were admitted into Kuyha Isolation Hospital run by Mekelle University College of Health Sciences, Mekelle, Northern part of Ethiopia for isolation and treatment. Patients were admitted irrespective of the clinical severity status. Admitted patients receive supportive therapy according to clinical need. Patients with severe disease receive high-flow oxygen via nasal cannula or intubation as well as dexamethasone. All COVID-19 cases confirmed by PCR test result between July and October 2020 were included in this study.

Sociodemographic, clinical and laboratory data were collected using standardized Case Record Forms (CRFs) adapted from the International Severe Acute Respiratory and Emerging Infection Consortium's (ISARIC) CRFs for emerging severe acute respiratory infections [21]. Patient's clinical status was stratified following WHO criteria as asymptomatic, mild/moderate, severe (with dyspnea, respiratory rate $\geq 30$ breaths per minute, $\mathrm{O}_{2}$ saturation $\leq 93 \%$, lung infiltrates $\geq$ $50 \%$ of the lung fields within $24-48$ hours), and critical (with respiratory failure, septic shock, and/or multiple organ failure) [22]. All data were then entered onto electronic medical records.

\section{Laboratory analysis:}

SARS-CoV-2 infection was confirmed by RT-PCR on samples obtained from nasopharyngeal swabs, according to WHO guidelines. Fresh stool sample specimens were obtained for examination for ova and parasites. Analysis included direct microscopic examination and modified Ritchie concentration method [23]. In addition, the intensity of infection was determined using Kato-Katz method and was calculated and reported as individuals' eggs per gram of feces (EPG), as described previously [23, 24] and recommended by the WHO [25]. Helminth-positive individuals were stratified into three infection intensity categories: (i) light (199 EPG), (ii) moderate (100-399 EPG), and (iii) heavy ( $\geq 400$ EPG).

\section{Ethical considerations:}

Patients enrolled provided written consent to participate in to the Profile-CoV study. The study protocol was reviewed and approved by the Health Research Ethics Review Committee (HRERC) 
medRxiv preprint doi: https://doi.org/10.1101/2021.02.02.21250995; this version posted February 3, 2021. The copyright holder for this preprint (which was not certified by peer review) is the author/funder, who has granted medRxiv a license to display the preprint in perpetuity. All rights reserved. No reuse allowed without permission.

of Mekelle University College of Health Sciences (\#ERC 1769/2020). All individual identifiers were de-linked from the original sources.

\section{Statistical analysis:}

The primary outcome for this study was the proportion of COVID-19 patients who developed severe disease among patients with and without a parasitic co-infection. Asymptomatic and $\mathrm{mild} /$ moderate cases were classified as non-severe cases and both severe and critical were classified as severe cases. Baseline characteristics for continuous variables were expressed as the median with interquartile range (IQR), and for categorical variables as proportions. Whereas categorical variables were compared using $\chi^{2}$ test or Fisher's exact test, categorical variables were compared by Mann-Whitney $U$ or Kruskal-Wallis tests, as appropriate. The association between parasitic co-infection and COVID-19 severity was determined by logistic regression analysis. Independent variables, including age, sex, comorbidity, parasite infection (overall and disaggregated by parasite type into protozoa and helminths), were included in the initial univariate analysis. Then a multivariate regression analyses [adjusted odds ratio (aOR)] were calculated (with backward stepwise elimination) by including all variables that were $p<0.20$ by univariate analysis. P values $<0.05$ were considered statistically significant. Data was analyzed using STATA (Statistical package v. 14.0, StataCorp, Texas, USA).

\section{Results}

Baseline socio-demographic data of the study participants is summarized in Table 1. The majority of our study population were male (62.5\%). The median age of the cohort was 32 (IQR 26-43) years, the majority $(60.7 \%)$ being in the age range 24 to 44 years. Most notably, $86.8 \%$ the cohort population were either asymptomatic or had mild/moderate symptoms at the time of diagnosis. The remaining (13.2\%) had either severe disease or required admission to intensive care unit (ICU). COVID-19 patients with severe disease tended to be older and had had significantly higher symptoms, including cough ( $82.4 \%$ vs. $21.9 \%)$, dyspnea (70.6\% vs. $2.9 \%)$, fever (61.8\% vs. $13.9 \%)$, head ache (41.2\% vs. $15.4 \%)$, chest pain ( $25.0 \%$ vs. $1.1 \%)$, myalgia $(25.0 \%$ vs. $3.1 \%)$, sore throat ( $20.6 \%$ vs. $4.3 \%)$, hemoptysis ( $13.2 \%$ vs. $1.6 \%$ ) and diarrhea (5.9\% vs. $1.3 \%)$, when compared to those presenting with non-severe form of COVID-19.

Of the total 515 individuals enrolled in the study, 267 (51.8\%) harbored one or more intestinal parasites (Table 2). Protozoa and helminth infections comprised $28.4 \%$ and $33.8 \%$, respectively. The most common protozoa infections were Entamoeba spp. (23.5\%) and Giardia (4.6\%). Among helminths, the most common infections were $H$. nana (21.2\%), S. mansoni $(6.2 \%)$, and $A$. lumbricoides (4.9\%). There was no difference in gender and age distribution when those with parasites were compared with those without parasites (Table 2). However, those without parasite co-infection presented with significant higher proportion of fever $(25.0 \%$ vs. $15.7 \%)$, head ache (24.2\% vs. $13.9 \%$ ), dyspnea (18.2\% vs $6.0 \%$ ) and hemoptysis (5.7\% vs. $0.8 \%$ ) than those with parasite co-infection. In addition, the proportion of comorbid conditions, in particular NCDs, 
medRxiv preprint doi: https://doi.org/10.1101/2021.02.02.21250995; this version posted February 3, 2021. The copyright holder for this preprint (which was not certified by peer review) is the author/funder, who has granted medRxiv a license to display the preprint in perpetuity.

All rights reserved. No reuse allowed without permission.

were significantly higher in COVID-19 patients without parasitic co-infection when compared to those with parasitic co-infection (Table 1).

The proportion of COVID-19 patients with parasitic infection decreased with increasing categories of disease severity, in particular for any parasitic and helminthic infections (Figure 1). In addition, clinical outcomes were considerably worse in COVID-19 patients without parasites (Table 1). Of all COVID-19 patients, a higher proportion of patients without parasitic co-infection were admitted to ICU and required supplemental oxygen compared to those with parasitic coinfection (Table 1). Severe COVID-19 was significantly higher in patients without parasites [47/248 (19.0\%, Cl: 14.52-24.35)] than in those with parasites [21/267 (7.9\%, Cl: 5.17-11.79)]; $\mathrm{p}<0.0001$. There was a significantly higher proportion of patients who developed severe COVID19 in the non-protozoa group [56/369 (15.2\%, Cl: 11.85-19.23)] as compared to the protozoa group [12/146 (8.2\%, Cl: 4.70-14.00)]; $\mathrm{p}=0.036$. Significant higher proportion of the patients presented at baseline with severe COVID-19 in the helminth negative group [57/341 $(16.7 \%, \mathrm{Cl}$ : $13.10-21.08)]$ than in the group with pre-existing helminth infection [11/174 (6.3\%, $\mathrm{Cl}$ : $3.51-$ 11.11)]; $p=0.001$. However, we did not observe any correlation between helminth egg-load with COVID-19 severity.

In univariate analysis, older age, diabetes, hypertension, cardio-vascular diseases, chronic obstructive lung diseases, chronic liver disease, and chronic kidney disease were all associated with increased likelihood of COVID-19 severity (Table 3). In the contrary, having any parasite, protozoal infection and helminth infections were all associated with reduced probability of severe COVID-19. In multivariate analysis, older age, hypertension and chronic kidney diseases were associated with the odds of COVID-19 severity. In addition, after adjustment for age and presence of comorbidities, COVID-19 patients with any parasite co-infection [aOR $0.41(95 \% \mathrm{Cl}$ : 0.22-0.77); $p=0.006$; Table 3], or with protozoa co-infection [aOR 0.45 (95\% Cl: 0.21-0.98); $\mathrm{p}=0.044$ ] as well as those with helminth co-infection [aOR 0.37 (95\% Cl: 0.17-0.80); $\mathrm{p}=0.011$ ] had lower probability of developing severe COVID-19 compared with those without parasite, protozoa or helminth co-infection. Interestingly, we noted that the odds of having a NCD was significantly lower in COVID-19 patients having co-infection with parasites (OR: 0.52 95\% Cl: 0.3090.2, $\mathrm{p}=0.020$ ), or helminths (OR 0.26 95\% Cl: 0.12-0.56; $\mathrm{p}=0.001$ ).

\section{Discussion}

This study demonstrated that co-infection with enteric parasites, both protozoa and helminths, was associated with lower probability of developing severe COVID-19. To the best of our knowledge, the findings represent the first report regarding an association between parasites and COVID-19 severity. Notably, the association was maintained even after adjusting for age and presence of comorbid conditions, factors commonly associated with COVID-19 severity.

In addition, previous reports have demonstrated that helminthic infection reduces the risk of development of diabetes and metabolic syndrome in humans [26-34]. This is in line with our 
medRxiv preprint doi: https://doi.org/10.1101/2021.02.02.21250995; this version posted February 3, 2021. The copyright holder for this preprint (which was not certified by peer review) is the author/funder, who has granted medRxiv a license to display the preprint in perpetuity.

All rights reserved. No reuse allowed without permission.

finding that pre-existing chronic co-infection with parasites/helminths in our cohort was associated with a significant lower proportion and reduced risk of NCDs. This may suggest that the observed decreased COVID-19 severity in our cohort might be attributed through decreased NCD risk.

The pathogenesis of severe disease in COVID-19 has been linked to the phenomenon of immune hyperactivation $[35,36]$, that resembles that of chronic inflammatory condition, such as hypertension, obesity, diabetes and inflammatory bowel diseases [37-41]. It is possible, therefore, that parasites mute COVID-19 severity through their effects in modulating systemic immune response. Parasitic infections modulate human's immune systems, in such a way that the T-helper $(\mathrm{TH})$ responses are augmented along with predominant regulatory (Treg) responses [11]. This parasite-driven $\mathrm{TH} 2$ response, in turn, may counterbalances $\mathrm{TH} 1$ responses, responsible for the hyperinflammation associated with severe COVID-19 [11]. In addition, parasite-driven gut microbiome changes may modulate the host's immune response [12]. Thus, it is possible that parasitic infections may affect pathogenesis both through direct modulation of the immune system as well as through parasite-driven microbiome balance. Indeed, it has been demonstrated in animal models that enteric helminth protect against pulmonary viral infections through interaction with microbiota [42].

The strengths of the current study include the prospective nature of the study design. However, our study has some limitations. First, stool samples were not able to be collected for every consecutive patient which may have resulted in a potential selection bias. Second, stool examination was determined by microscopy only. The presence of very low intensity parasite infection determined by PCR, though shown to be superior to microscopy with increased sensitivity and specificity [43], might indeed preclude the effects on immune modulation to have any significant effect. Third, the effect of individual parasite species on COVID-19 severity could not be ascertained in the current study because of the small sample size in groups with different parasite species. Finally, the inclusion of smaller proportion of severe cases as compared to nonsevere cases in our cohort may potentially bias the results.

In conclusion, our study demonstrates for the first time that pre-existing parasitic infection, both with protozoa and helminths, may provide some sort of protection from the pathology linked with severe COVID-19. This is corroborated by the observed low fatality rate of COVID-19 in LMICS settings where parasitic infections are endemic [15, 18, 20,44]. We also recommend to expand the study to other LMICs and also include the effect of the interplay between parasitemicrobiome on COVID-19 severity. Unraveling the mechanisms underlying severe COVID-19 offers avenues for novel preventive and therapeutic interventions. 
medRxiv preprint doi: https://doi.org/10.1101/2021.02.02.21250995; this version posted February 3, 2021. The copyright holder for this preprint (which was not certified by peer review) is the author/funder, who has granted medRxiv a license to display the preprint in perpetuity. All rights reserved. No reuse allowed without permission.

\section{Acknowledgement}

We thank all the staff for their contribution and the study participants for their cooperation. This research was supported by grants from the European and Developing Countries Clinical Trials Partnership (EDCTP), supported by the European Union (RIA-2020EF-2095) and Joep Lange Institute for Global Health and Development, The Netherlands.

\section{References:}

1. Huang C, Wang Y, Li X, Ren L, Zhao J, Hu Y et al. Clinical features of patients infected with 2019 novel coronavirus in Wuhan, China. Lancet. 2020; 395:497-506. doi:10.1016/S01406736(20)30183-5.

2. Yang $X, Y u Y, X u J$, Shu H, Xia J, Liu H et al. Clinical course and outcomes of critically ill patients with SARS-CoV-2 pneumonia in Wuhan, China: a single-centered, retrospective, observational study. Lancet Respir Med. 2020. [Epub 2020/02/28]. doi:10.1016/S2213-2600(20)30079-5.

3. Chen N, Zhou M, Dong X, et al. Epidemiological and clinical characteristics of 99 cases of 2019 novel coronavirus pneumonia in Wuhan, China: a descriptive study. Lancet 2020; 395: 50713.

4. Zhou F, Yu T, Du R, Fan G, Liu Y, Liu Z et al. Clinical course and risk factors for mortality of adult inpatients with COVID-19 in Wuhan, China: a retrospective study. Lancet, 2020. doi: 1016/S0140- 6736(20)30566-3.

5. Cummings MJ, Baldwin MR, Abrams D, et al. Epidemiology, clinical course, and outcomes of critically ill adults with COVID-19 in New York City: a prospective cohort study. Lancet 2020; 395: 1763-1770.

6. Richardson S, Hirsch JS, Narasimhan M, et al. Presenting characteristics, comorbidities, and outcomes among 5700 patients hospitalized with COVID-19 in the New York City Area. JAMA 2020; 323: 2052-2059.

7. Grasselli G, Zangrillo A, Zanella A, et al. Baseline characteristics and outcomes of 1591 patients infected with SARS-CoV-2 admitted to ICUs of the Lombardy Region, Italy. JAMA 2020; 323: 1574-1581.

8. Wu C, Chen X, Cai Y, et al. Risk factors associated with acute respiratory distress syndrome and death in patients with coronavirus disease 2019 Pneumonia in Wuhan, China. JAMA Intern Med 2020; 180: 934-943.

9. Hotez PJ, Alvarado M, Basanez MG, Bolliger I, Bourne R, Boussinesq M, et al. The global burden of disease study 2010: interpretation and implications for the neglected tropical diseases. PLoS NegI Trop Dis. 2014; 8:e2865. https://doi.org/10.1371/journal.pntd.0002865 PMID: 25058013

10. Herricks JR, Hotez PJ, Wanga V, Coffeng LE, Haagsma JA, Basáñez M-G, et al. The global burden of disease study 2013: What does it mean for the NTDs? PLoS NegI Trop Dis. 2017; 11:e0005424. 
medRxiv preprint doi: https://doi.org/10.1101/2021.02.02.21250995; this version posted February 3, 2021. The copyright holder for this preprint (which was not certified by peer review) is the author/funder, who has granted medRxiv a license to display the preprint in perpetuity.

All rights reserved. No reuse allowed without permission.

11. White MPJ, McManus CM, Maizels RM. Regulatory T-cells in helminth infection: induction, function and therapeutic potential. Immunology. 2020;160:248-260.doi:10.1111/imm.13190

12. Chabé M, Lokmer A, Ségurel L. Gut Protozoa: Friends or Foes of the Human Gut Microbiota? Trends Parasitol. (2017) 33:925-934. doi:10.1016/j.pt.2017.08.005

13. Bradbury RS, Piedrafita D, Greenhill A, Mahanty S. Will helminth co-infection modulate COVID-19 severity in endemic regions? [Published online ahead of print, 2020 May 1]. Nat Rev Immunol 2020. doi: 10.1038/s41577-020-0330-5

14. Gutman, JR, Lucchi NW, Cantey PT, Steinhardt LC, Samuels AM, Kamb ML, Kapella BK, et al. Malaria and parasitic neglected tropical diseases: Potential syndemics with COVID-19? Am J Trop Med Hyg 2020; 103(2); 572-577. doi:10.4269/ajtmh.20-0516

15. Mbow M, Lell B, Jochems SP, Cisse B, Mboup S, Dewals BG, Jaye A, et al. COVID-19 in Africa: Dampening the storm? Science 2020; 369: 624-626. doi:10.1126/science.abd3902

16. Hays R, Pierce D, Giacomin P, Loukas A, Bourke P, McDermott R. Helminth co-infection and COVID-19: An alternate hypothesis. PLoS Negl Trop Dis 2020; 14: e0008628. https://doi. org/10.1371/journal.pntd.0008628

17. Cepon-Robins TJ, Gildner TE. Old friends meet a new foe: A potential role for immune-priming parasites in mitigating COVID-19 morbidity and mortality. Evol Med Public Health 2020; 2020:234-248.doi:10.1093/emph/eoaa037

18. Fonte L, Acosta A, Sarmiento ME, Ginori M, Garcia G, Norazmi MN. COVID-19 lethality in SubSaharan Africa and helminth immune modulation. Front Immunol 2020; 11:574910. doi:10.3389/fimmu.2020.574910

19. Siles-Lucas M, González-Miguel J, Geller R, Sanjuan R, Pérez-Arévalo J, Martínez-Moreno A. Potential influence of helminth molecules on COVID-19 pathology. Trends Parasitol 2020; 37:11-14. doi:10.1016/j.pt.2020.10.002

20. Ssebambulidde K, Segawa I, Abuga KM, Nakate V, Kayiira A, Ellis J, Tugume L, et al. Parasites and their protection against COVID-19 - Ecology or Immunology? medRxivdoi:10.1101/2020.05.11.20098

21. International Severe Acute Respiratory and Emerging Infection Consortium (ISARIC). COVID19 CRF. Available at: https://isaric.tghn.org/COVID-19- CRF/ (accessed Aug 28, 2020).

22. WHO (2020) Report of the WHO-China Joint Mission on Coronavirus Disease 2019 (COVID19). https://www.who.int/docs/default-source/coronavi ruse/who-china-jointmission-oncovid-19-final-report.pdf [accessed 28 March 2020].

23. Mahmud MA, Spigt M, Bezabih AM, et al. Efficacy of handwashing with soap and nail clipping on intestinal parasitic infections in school-aged children: A factorial cluster randomized controlled trial. PLos Med 2015; 12:e1001837.

24. Mahmud MA, Spigt M, Bezabih AM, et al. Risk factors for intestinal parasitosis, anemia and malnutrition among school children in Ethiopia. Pathog Glob Health 2013; 107: 58-65.

25. WHO. Prevention and control of schistosomiasis and soil-transmitted helminthiasis. World Health Organ Tech Rep Ser 2002; 912: i-vi. 1-57 
medRxiv preprint doi: https://doi.org/10.1101/2021.02.02.21250995; this version posted February 3, 2021. The copyright holder for this preprint (which was not certified by peer review) is the author/funder, who has granted medRxiv a license to display the preprint in perpetuity.

All rights reserved. No reuse allowed without permission.

26. Chen Y, Lu J, Huang Y, et al. Association of previous schistosome infection with diabetes and metabolic syndrome: a cross-sectional study in rural China. J Clin Endocrinol Metab 2013; 98:E283-287.

27. Duan Q, Xiong L, Liao C, et al. Population based and animal study on the effects of Schistosoma japonicum infection in the regulation of host glucose homeostasis. Acta Trop 2018; 180:33-41.

28. Hays R, Esterman A, Giacomin P, Loukas A, McDermott R. Does Strongyloides stercoralis infection protect against type 2 diabetes in humans? Evidence from Australian Aboriginal adults. Diabetes Res Clin Pract 2015; 107:355-61.

29. Hays R, Giacomin P, Olma L, Esterman A, McDermott R. The relationship between treatment for Strongyloides stercoralis infection and type 2 diabetes mellitus in an Australian Aboriginal population: a three-year cohort study. Diabetes Res Clin Pract 2017; 134:8-16.

30. Vasunilashorn S, Crimmins EM, Kim JK, et al. Blood lipids, infection, and inflammatory markers in the Tsimane of Bolivia. Am J Hum Biol 2010; 22:731-740.

31. Magen E, Bychkov V, Ginovker A, Kashuba E. Chronic Opisthorchis felineus infection attenuates atherosclerosis - an autopsy study. Int J Parasitol 2013; 43:819-824.

32. Wiria AE, Hamid F, Wammes LJ, et al.Infection with soil-transmitted helminths is associated with increased insulin sensitivity. PLoS One 2015; 10:e0127746

33. Rajamanickam A, Munisankar S, Dolla C, Menon PA, Thiruvengadam K, Nutman TB, et al. Helminth infection modulates systemic pro-inflammatory cytokines and chemokines implicated in type 2 diabetes mellitus pathogenesis. PLoS Negl Trop Dis 2020; 14: e0008101. doi:10.1371/journal. pntd.0008101

34. Sanya RE, Webb EL, Zziwa C, Kizindo R, Sewankambo M, Tumusiime J, Nakazibwe E, et al. The effect of helminth infections and their treatment on metabolic outcomes: results of a clusterrandomized trial. Clin Infect Dis 2020; 71: 601-613. doi:10.1093/cid/ciz859

35. Tay MZ, Poh CM, Rénia L, MacAry PA, Ng LFP. The trinity of COVID-19: immunity, inflammation and intervention. Nat Rev Immunol. 2020; 20:363-374. doi:10.1038/s41577020-0311-8

36. Sinha P, Matthay MA, Calfee CS. Is a "cytokine storm" relevant to COVID-19. JAMA Intern Med. 2020. Epub ahead of print. doi: 10.1001/jamainternmed.2020.3313

37. Donath MY, Shoelson SE. Type 2 diabetes as an inflammatory disease. Nat Rev Immunol 2011; 11:98-107.

38. Fang L, Karakiulakis G, Roth $M$. Are patients with hypertension and diabetes mellitus at increased risk for COVID-19 infection? Lancet Respir Med 2020; 8:e21. doi: 10.1016/S22132600(20)30116-8

39. Hill MA, Mantzoros C, Sowers JR. Commentary: COVID- 19 in patients with diabetes. Metabolism. 2020; 107:154217. doi: 10.1016/j.metabol.2020.154217

40. Li F, Wang M, Wang J, Li R, Zhang Y. Alterations to the gut microbiota and their correlation with inflammatory factors in chronic kidney disease. Front Cell Infect Microbiol. (2019) 9:206217. doi:10.3389/fcimb.2019.00206 
medRxiv preprint doi: https://doi.org/10.1101/2021.02.02.21250995; this version posted February 3, 2021. The copyright holder for this preprint

(which was not certified by peer review) is the author/funder, who has granted medRxiv a license to display the preprint in perpetuity.

All rights reserved. No reuse allowed without permission.

41. Shaw KA, Bertha M, Hofmekler T, et al. Dysbiosis, inflammation, and response to treatment: a longitudinal study of pediatric subjects with newly diagnosed inflammatory bowel disease. Genome Med. (2016) 8:75-88. doi:10.1186/s13073-016-0331-y

42. McFarlane AJ, McSorley HJ, Davidson DJ, Fitch PM, Errington C, Mackenzie KJ, Gollwitzer ES, et al. Enteric helminth-induced type I interferon signaling protects against pulmonary virus infection through interaction with the microbiota. J Allergy Clin Immunol. 2017; 140: 10681078. doi:10.1016/j.jaci.2017.01.016

43. Llewellyn S, Inpankaew T, Nery SV, Gray DJ, Verweij JJ, Clements ACA, et al. Application of a multiplex quantitative PCR to assess prevalence and intensity of intestinal parasite infections in a controlled clinical trial. PLoS Negl Trop Dis 2016; 10: e0004380. doi:10.1371/journal. pntd.0004380

44. Chatterjee B, Karandikar RL, mande SC. Paradoxical case fatality rate dichotomy of COVID19 among rich and poor nations points to the "hygiene hypothesis". medRxiv 2020.

doi:10.1101/2020.07.31.20165696. 
Table 1. Clinical features among COVID-19 patients without or with parasitic co-infection

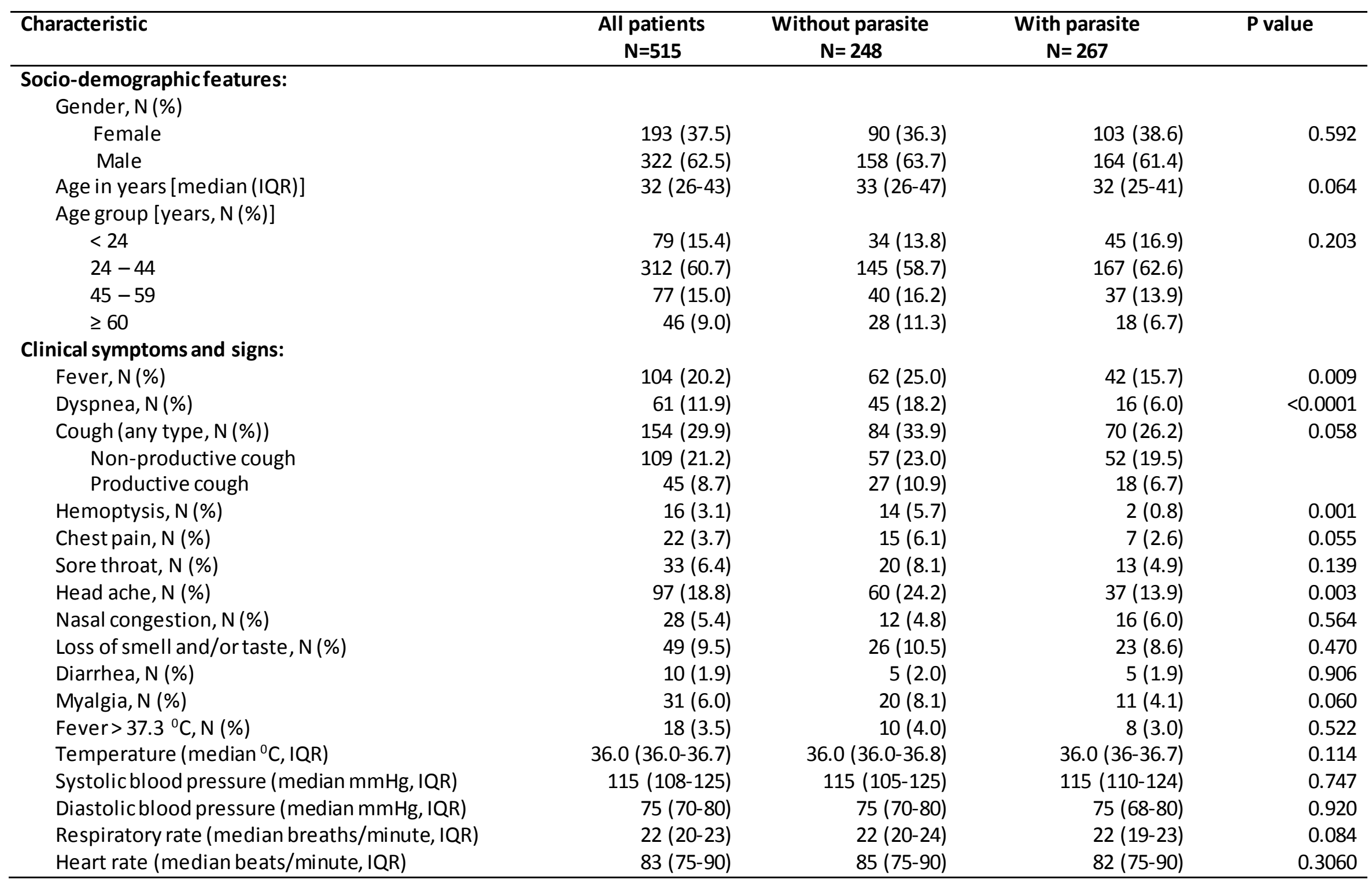




\begin{tabular}{|c|c|c|c|c|}
\hline \multicolumn{5}{|l|}{ Comorbidities } \\
\hline Comorbidity (at least 1) & $78(15.2)$ & $49(19.8)$ & 29 (10.9) & 0.005 \\
\hline Diabetes & $31(6.0)$ & $22(8.9)$ & $9(3.4)$ & 0.009 \\
\hline Cardio-vascular diseases & $5(1.0)$ & $4(1.6)$ & $1(0.4)$ & 0.152 \\
\hline Chronic obstructive lung diseases and asthma & $14(2.7)$ & $10(4.0)$ & $4(1.5)$ & 0.077 \\
\hline Chronicliverdisease & $3(0.6)$ & $3(1.2)$ & $0(0.0)$ & 0.071 \\
\hline HIV & $8(1.6)$ & $5(2.0)$ & $3(1.1)$ & 0.410 \\
\hline Tuberculosis & $1(0.2)$ & $1(0.4)$ & $0(0.0)$ & 0.298 \\
\hline \multicolumn{5}{|l|}{ Outcomes } \\
\hline Admission to ICU & $29(5.6)$ & $20(8.1)$ & $9(3.4)$ & 0.021 \\
\hline Supplemental oxygen & $68(13.2)$ & $47(19.0)$ & $21(7 . .9)$ & $<0.0001$ \\
\hline Invasive mechanical ventilation & $13(2.5)$ & $9(3.6)$ & $4(1.5)$ & 0.123 \\
\hline
\end{tabular}


Table 2. Clinical features and prevalence of parasitic infections among non-severe and severe COVID-19 patients

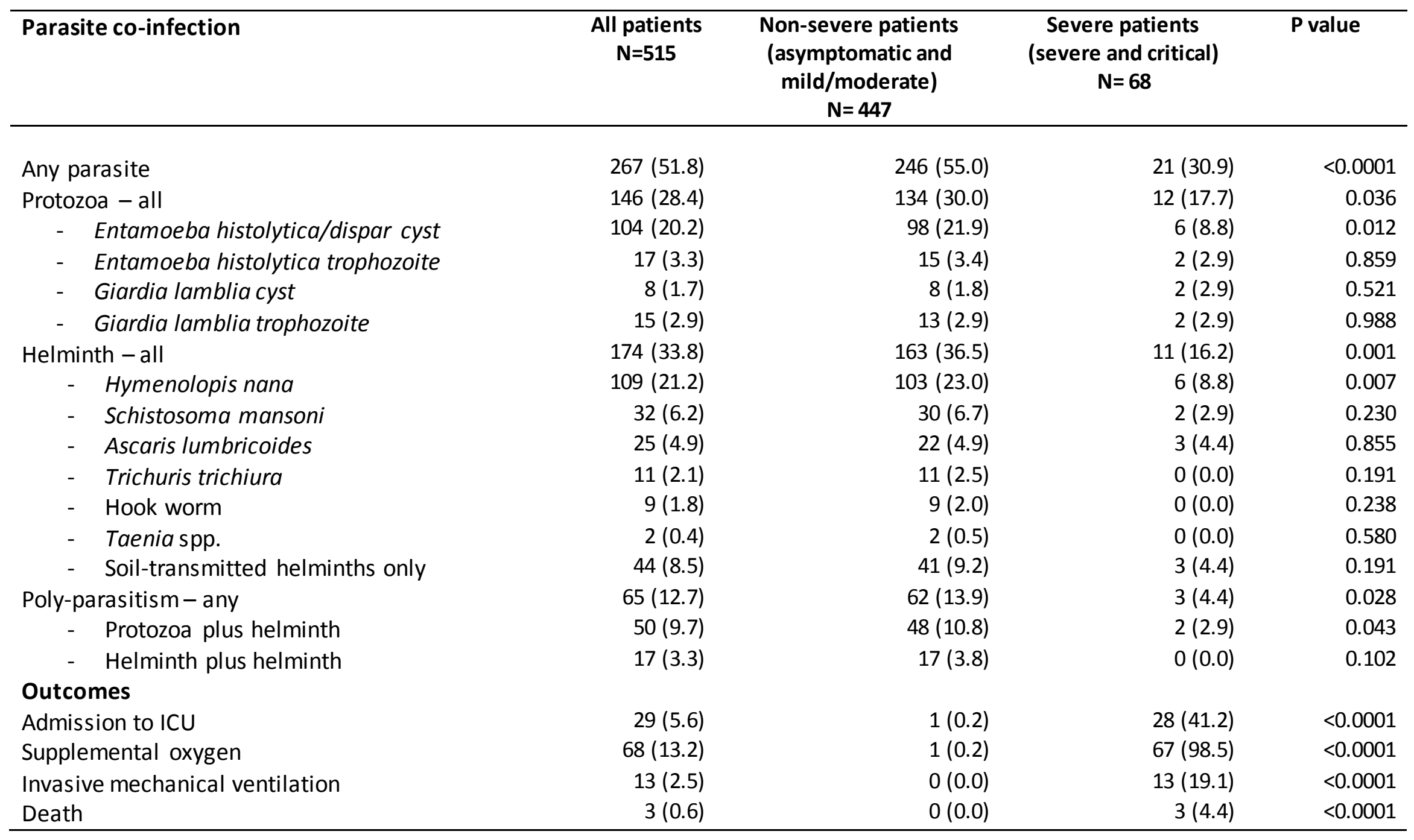


medRxiv preprint doi: https://doi.org/10.1101/2021.02.02.21250995; this version posted February 3, 2021. The copyright holder for this preprint (which was not certified by peer review) is the author/funder, who has granted medRxiv a license to display the preprint in perpetuity. All rights reserved. No reuse allowed without permission.

Table 3. Factors associated with severity among COVID-19 patients in Northern Ethiopia

\begin{tabular}{|c|c|c|c|c|}
\hline Characteristic & $\begin{array}{c}\text { Unadjusted Odds } \\
\text { Ratio } \\
(95 \% \mathrm{Cl}) \\
\end{array}$ & $P$-value & $\begin{array}{c}\text { Adjusted Odds } \\
\text { Ratio* } \\
(95 \% \mathrm{Cl})\end{array}$ & $P$-value \\
\hline Gender(male vs female) & $1.51(0.87-2.64)$ & 0.142 & & \\
\hline Age (per 10 years increase) & $2.10(1.76-2.51)$ & $<0.0001$ & $1.92(1.59-2.33)$ & $<0.0001$ \\
\hline Comorbidity (at least 1 )* & $18.44(10.16-33.47)$ & $<0.0001$ & $10.67(5.58-20.43)$ & $<0.0001$ \\
\hline $\begin{array}{l}\text { Non-communicable disease (NCDs) } \\
\text { comorbidities* }\end{array}$ & $17.17(9.25-31.89)$ & $<0.0001$ & $8.90(4.48-17.67)$ & $<0.0001$ \\
\hline Diabetes & $6.56(3.06-14.05)$ & $<0.0001$ & $1.12(0.42-3.00)$ & 0.814 \\
\hline Hypertension & $18.87(8.10-43.99)$ & $<0.0001$ & $8.21(3.02-22.29)$ & $<0.0001$ \\
\hline Cardio-vascular diseases & $10.27(1.68-62.63)$ & 0.012 & $3.81(0.39-37.07)$ & 0.250 \\
\hline Chronic obstructive lung diseases & $3.86(1.25-11.89)$ & 0.019 & $1.28(0.28-5.88)$ & 0.758 \\
\hline Chronic kidney disease & $5.11(1.12-23.35)$ & 0.035 & $9.12(1.43-58.21)$ & 0.019 \\
\hline Chronicliver disease & $13.52(1.21-151.13)$ & 0.035 & $0.75(0.02-31.15)$ & 0.882 \\
\hline \multicolumn{5}{|l|}{$\begin{array}{l}\text { Communicable disease } \\
\text { comorbidities }\end{array}$} \\
\hline HIV & $2.22(0.44-11.24)$ & 0.334 & & \\
\hline Tuberculosis & 1.0 & -- & & \\
\hline \multicolumn{5}{|l|}{ Parasite co-infection } \\
\hline Any parasite (at least 1$)^{*}$ & $0.37(0.21-0.63)$ & $<0.0001$ & $0.41(0.22-0.77)$ & 0.006 \\
\hline Protozoa** & $0.50(0.26-0.96)$ & 0.039 & $0.45(0.21-0.98)$ & 0.044 \\
\hline Helminth** & $0.34(0.17-0.66)$ & 0.002 & $0.37(0.17-0.80)$ & 0.011 \\
\hline
\end{tabular}

Adjusted for age*, or for both age and NCDs** 


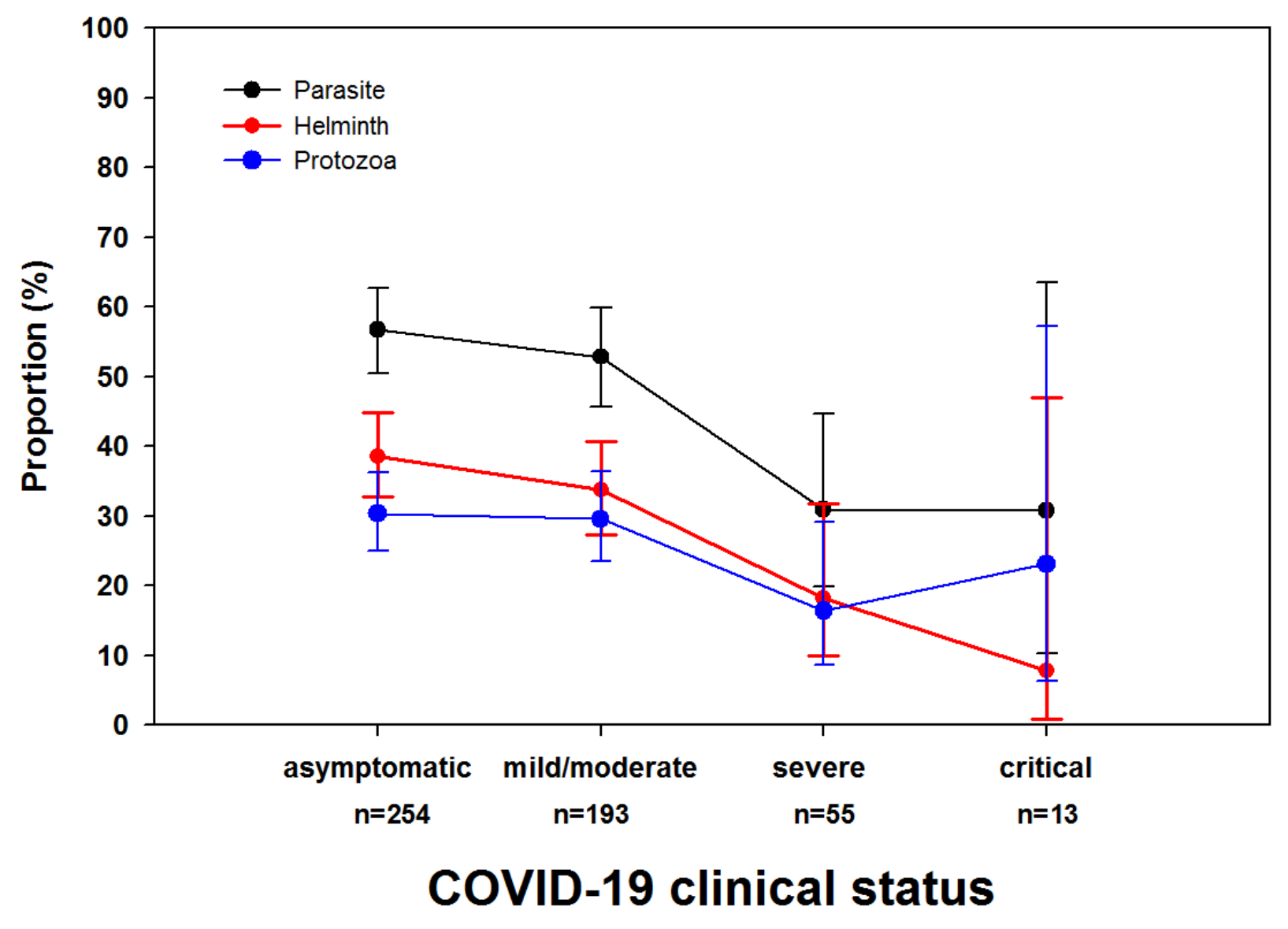

Figure 1. Proportion of parasites, protozoa and helminths among COVID-19 patients with asymptomatic, mild/moderate, severe and critical clinical presentation. P-values for trend $(p=0.002, p=0.006$ and $p=0.196$ for any parasite, helminth and protozoa, respectively). 